\title{
KAJIAN MASYARAKAT MISKIN DI KOTA SEMARANG: SUATU REFLEKSI GAYA HIDUP
}

\author{
Bambang, Alam Pradita W dan Luqman Hakim \\ Universitas Diponegoro \\ e-mail : punakawan_cirebon@yahoo.co.id
}

\begin{abstract}
The problem of poverty is suspected as old as human life itself. While social scientists agree that the main cause of poverty was economic system prevailing in the society, but poverty itself is not the problem that manifested because of only the economic system. In fact, poverty is a manifestation of human interaction that involves virtually all aspects belonging to the human life, so that the problem is not endless.

Problems that occur in urban poverty believed to be caused not only by low incomes, but also by the mindset of respondents that made respondents static. This mindset was reflected in a lifestyle that could be seen from the behavior of consumption, investment, use of leisure time and concern for the salvation of the souls of respondents (safety). It was expected to become the foundation to be used in solving the problems faced by the urban poor and what solutions can be given.

With SPSS analysis tool that generated tabulation summarizes, arrangement or compilation of data in the form of numeric tables would explain how the characteristics and description from the lifestyle of the urban poor as a real form of the mindset of the respondents. The results of this study indicated that the majority of the urban poor over the age of 51 years and only educated to primary school. Environmental conditions and poor sanitation, inadequate nutrition fulfillment, availability of adequate clothing though limited, the recreation area around the city of Semarang and concern for the salvation of the souls of respondents who still lack was a general overview from the results of analyzes performed.
\end{abstract}

Keyword: urban poverty, lifestyle, consumption, investment, safety, leisure

\section{PENDAHULUAN}

Isu nyata dalam pembangunan adalah manusia (Todaro, 2003). Hal ini menyangkut bagaimana pembangunan seharusnya mampu untuk memenuhi tujuan manusia yaitu meningkatkan kesejahteraan dan menyelesaikan permasalahan manusia. Salah satu permasalahan tersebut yaitu kemiskinan. Kemiskinan merupakan permasalahan yang diduga sama tuanya dengan usia manusia itu sendiri. Walaupun para ahli ilmu sosial sependapat bahwa sebab utama yang melahirkan kemiskinan adalah sistem ekonomi yang berlaku dalam masyarakat, tetapi kemiskinan itu sendiri bukanlah sesuatu gejala yang terwujud semata-mata hanya karena sistem ekonomi tersebut. Dalam kenyataannya kemiskinan merupakan perwujudan dari hasil interaksi manusia yang melibatkan hampir semua aspek-aspek yang dipunyai manusia dalam kehidupannya (Pasudi Suparlan, 1984). 
Urgensi permasalahan kemiskinan ini dapat dilihat dari publikasi Asian Development Bank (ADB) bahwa pada tahun 2005, 36,1 juta jiwa $(16,6 \%)$ penduduk hidup di bawah garis kemiskinan dan 100 juta jiwa penduduk masuk kategori sejahtera-I (pendapatan kurang dari US\$2 tiap hari). Sedangkan berdasarkan data BPS untuk penerima subsidi langsung tunai (SLT) terdapat 14 juta rumah tangga miskin yang tergolong dalam kelompok fakir miskin dan prasejahtera. Bahkan mantan sekjen PBB, Kofi Anan, pada pertemuan G77 yang diselenggarakan UNCTAD di Sao Paulo Brasil tanggal 15 Juni 2004 menyatakan bahwa setiap lima detik ada seorang bayi yang meninggal akibat kegagalan dunia memerangi kemiskinan. Kegagalan menjangkau pendidikan, kesehatan, dan target-target anti kelaparan pada tahun 2015 akan membawa generasi di negaranegara berkembang menuju pada kehidupan yang malang (Kompas, 2004).

Perhitungan kemiskinan di atas seharusnya tidak dilihat hanya dari sudut pandang badan yang mengukur kemiskinan saja dan sangat kental dengan matematisnya. Namun juga harus mempertimbangkan pertimbangan sudut pandang dari objek kemiskinan. Diduga bahwa manusia mengalami kemiskinan tidak hanya disebabkan oleh pendapatannya yang rendah tetapi juga lebih disebabkan oleh sifat statis orang miskin yang tidak ada kemauan untuk berusaha dari keterpurukannya. Ini tidak lain merupakan bentuk pola pikir masyarakat miskin yang sudah tidak memiliki motivasi untuk berubah dan kemudian tampak dalam pola hidup dan etos kerja responden (Dowling, 2004)

Jumlah penduduk miskin di perkotaan dari tahun ke tahun pasti lebih besar daripada jumlah penduduk miskin di pedesaan (Badan Pusat Statistik, 2006). Ini menandakan bahwa permasalahan kemiskinan di perkotaan akan sangat kompleks tidak hanya dilihat dari jumlah penduduk yang banyak, tetapi juga dilihat dari berbagai aspek baik penyebab maupun permasalahan yang dihadapi penduduk miskin di perkotaan. Dengan menganalisis pola pikir dan gaya hidup masyarakat miskin di perkotaan, diharapkan akan memberikan penjelasan tentang karakteristik di balik kehidupan responden. Melalui hal ini diharapkan dapat ditemukan suatu jawaban sebagai solusi permasalahan kemiskinan di perkotaan.

\section{REVIEW LITERATUR DAN HIPOTESIS}

\section{Kemiskinan}

Dalam Kanbur dan quire (1999) dalam Meier dan Stiglitz (2000), secara konvensional kemiskinan dapat didefinisikan sebagai tahapan di mana orang memiliki posisi pendapatan kurang dari jumlah pendapatan atau materi yang dapat diterima secara sosial. Definisi tersebut memiliki dua penekanan, yaitu dapat diterima secara sosial dan kemampuan untuk membeli barang dan jasa. Dengan definisi kemiskinan tersebut, maka definisi kemiskinan akan berbeda pada perbedaan waktu dan perbedaan kehidupan sosial orang tersebut.

Dalam arti proper, kemiskinan dipahami sebagai keadaan kekurangan uang dan barang untuk menjamin kelangsungan hidup. Dalam arti luas, Chambers (dalam Suryawati, 2005) mengatakan bahwa kemiskinan adalah suatu intergrated concept yang memiliki lima dimensi, yaitu: 1) kemiskinan (proper), 2) keidakberdayaan (powerless), 3) kerentanan menghadapi situasi darurat (state of emergency), 4) ketergantungan (dependence), dan 5) keterasingan (isolation) baik secara geografis maupun sosiologis.

Untuk mengukur tingkat kemiskinan banyak definisi yang digunakan sebagai batas penentuan suatu penduduk apakah miskin atau tidak. Menurut Sayogyo (1971) dalam Cahyat (2004), tingkat kemiskinan didasarkan jumlah rupiah pengeluaran rumah tangga yang disetarakan dengan jumlah kilogram konsumsi beras per orang per tahun dan dibagi wilayah 
perdesaan dan perkotaan (Cahyat, 2004). Selanjutnya Sayogyo (1971) dalam Cahyat (2004) merinci ukuran kemiskinan di perdesaan sebagai berikut:

a. Miskin, bila pengeluaran keluarga lebih kecil daripada $320 \mathrm{~kg}$ nilai tukar beras per orang per tahun.

b. Miskin sekali, bila pengeluaran keluarga lebik kecil dari pada $240 \mathrm{~kg}$ nilai tukar beras per orang per tahun.

c. Paling miskin, bila pengeluaran keluarga lebih kecil dari pada $180 \mathrm{~kg}$ nilai tukar beras per orang per tahun.

Adapun ukuran kemiskinan di daerah perkotaan yaitu:

a. Miskin, apabila pengeluaran keluarga lebih kecil dari pada $480 \mathrm{~kg}$ nilai tukar beras per orang per tahun.

b. Miskin sekali, apabila pengeluaran keluarga lebih kecil dari pada $380 \mathrm{~kg}$ nilai tukar beras per orang per tahun.

c. Paling miskin, bila pengeluaran keluarga lebih kecil dari pada $270 \mathrm{~kg}$ nilai tukar beras per orang per tahun.

Bank Dunia mengukur garis kemiskinan berdasarkan pada pendapatan seseorang. Seseorang yang memiliki pendapatan kurang dari US\$ 2 per hari masuk dalam kategori miskin. Badan Koordinasi Keluarga Berencana Nasional (BKKBN), mengukur kemiskinan berdasarkan dua kriteria (Suryawati, 2005), yaitu:

a. Kriteria Keluarga Pra Sejahtera (Pra KS) yaitu keluarga yang tidak mempunyai kemampuan untuk menjalankan perintah agama dengan baik, minimum makan dua kali sehari, membeli lebih dari satu stel pakaian per orang per tahun, lantai rumah ber semen lebih dari $80 \%$, dan berobat ke Puskesmas bila sakit.

b. Kriteria Keluarga Sejahtera 1 (KS 1) yaitu keluarga yang tidak berkemampuan untuk melaksanakan perintah agama dengan baik, minimal satu kali per minggu makan daging/telur/ikan, membeli pakaian sau stel per tahun, rata-rata luas lantai rumah 8 meter persegi per anggota keluarga, tidak ada anggota keluarga umur 10 sampai 60 tahun yang buta huruf, semua anak berumur antara 5 sampai 15 tahun bersekolah, satu dari anggota keluarga berpenghasilan rutin atau tetap, dan tidak ada yang sakit selama tiga bulan.

\section{Kemiskinan Perkotaan}

Kemiskinan di perkotaan dipicu oleh perkembangan kota yang semakin pesat, tercermin dari pesatnya perluasan wilayah kota, tingginya tingkat urbanisasi, meningkatnya perkembangan ekonomi yang ditandai adanya konsentrasi berbagai macam kegiatan ekonomi, terutama industri, jasa-jasa modern, dan perdagangan. Perubahan sosial dan modernisasi kehidupan telah mengubah kehidupan pola konsumsi, gaya hidup, dan perilaku sosial menuju pada perbaikan kesejahteraan (Shalimow, 2004). Kemiskinan merupakan keadaan kekurangan barang dan pelayanan yang dibutuhkan untuk mencapai standar hidup yang layak, karena standar hidup tersebut berbeda-beda, maka tidak ada konsep kemiskinan yang universal. Adapun menurut Sumodiningrat (1998) kemiskinan adalah wujud dari kesenjangan antar kelompok sosial, jika ditinjau dalam segi keruangan, kemiskinan timbul karena ada sebagian daerah yang belum sepenuhnya tertangani, ada beberapa sektor yang menampung tenaga kerja berlebih dengan tingkat produktivitas yang rendah, dan ada pula kelompok masyarakat yang belum dapat merasakan hasilhasil pembangunan secara memadai. Kemiskinan juga dapat dilihat dari beberapa faktor yaitu angka ketergantungan rumah tangga yang tinggi, tingkat pendidikan yang rendah, kurangnya hak kepemilikan dan keamanan aset, pendapatan yang rendah atau pengangguran (McKay dan Kedir, 2005:49). 
Efisiensi pembangunan perkotaan sebenarnya memiliki peranan besar dalam memerangi kemiskinan nasional, baik dari pendatang baru yang memberikan peluang untuk kehidupan yang lebih baik dan dari perspektif negara dengan menyediakan sebuah pasar yang memiliki diversifikasi industri dan jasa dapat berkembang sebagai mesin pertumbuhan dari pendapatan nasional. Namun, perwujudan potensi keuntungan migrasi dari perdesaan ke perkotaan tergantung pada seberapa baik kota mampu mengatur pertumbuhan, menyediakan tata pemerintahan yang baik, dan memberikan pelayanan kepada penduduknya (Baharoglu dan Kessides, 2001). Kondisi perkotaan tidak dapat digeneralisasi karena adanya perbedaan ukuran kota yang cenderung memiliki berbagai masalah. Hal ini mempengaruhi besarnya pelayanan publik seperti perumahan dan kesehatan yang dapat diakses oleh penduduk. Menurut Brockerhorff dan Brennan (1998), kesejahteraan penduduk kota mengalami penurunan terutama di kota-kota besar di dunia. Hal ini menunjukkan kebijakan publik yang ditetapkan oleh pemerintah kurang merespon tekanan penduduk yang semakin besar. Lebih lanjut dijelaskan bahwa kegagalan pemerintah dalam menyediakan pelayanan perkotaan semakin memperparah kemiskinan.

Kemiskinan sering dilihat berdasarkan tingkat kesejahteraan penduduk yang juga dipengaruhi oleh kondisi sosial yang terbentuk dalam komunitas sehingga akan memberikan karakteristik kemiskinan yang berbeda antara wilayah satu dengan lainnya (Baharoglu dan Kessides, 2001). Dimensi kemiskinan merupakan ukuran kemiskinan yang biasanya dilihat dari tingkat kesejahteraan penduduk. Satu dimensi kemiskinan sering menyebabkan atau berkontribusi pada dimensi lain (Baharoglu dan Kessides, 2001). Hal ini menunjukkan adanya dampak kumulatif dari kemiskinan perkotaan. Lebih jelasnya dapat dilihat pada gambar di bawah ini:

\section{Gambar 1}

\section{Dampak Kumulatif Kemiskinan Perkotaan}

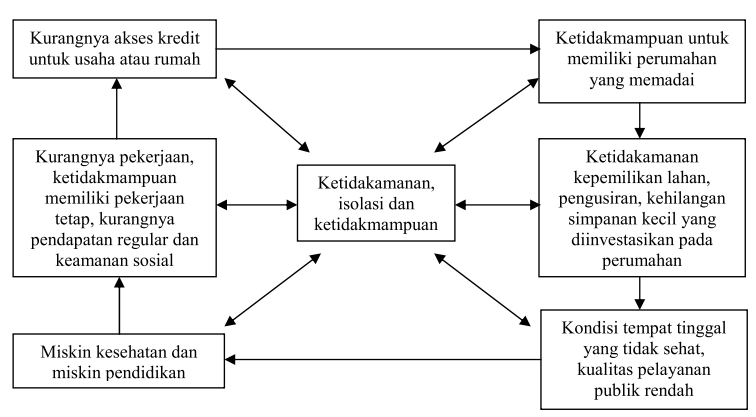

Sumber: diadopsi dari Baharoglu dan Kessides, 2001

\section{Gaya Hidup (Lifestyle)}

Pada mulanya, konsep mengenai gaya hidup diperkenalkan pertama kali oleh Adler. Pada masa itu, Adler mengatakan bahwa gaya hidup merupakan prinsip - prinsip idiografik yang dapat digunakan sebagai landasan untuk memahami tingkah laku dan keunikan individu yang akan melatar belakangi sifat khas yang dimilikinya. Kepribadian individual dapat berfungsi dengan adanya prinsip - prinsip tersebut. Adler juga menambahkan bahwa setiap orang mempunyai gaya hidup tetapi tidak mungkin ada dua orang yang mengembangkan gaya hidup yang sama (Hall \& Lindzey, 1993 dalam Alam, 2006).

Pernyataan demikian juga ditegaskan oleh Kotler (2002) dalam Alam (2006) yang mengatakan bahwa dalam diri seseorang terdapat sistem nilai (value system) yang berbeda dengan orang lain. Sistem nilai biasanya dapat dilihat melalui gaya hidup individu tersebut sehingga setiap individu dapat memiliki gaya hidup yang berbeda dengan individu lain meskipun berasal dari sub budaya, kelas sosial, maupun pekerjaan yang sama.

Adapun menurut World Health Organization (1998) gaya hidup adalah cara hidup berdasarkan pola perilaku yang dapat diidentifikasi yang ditentukan oleh antara 
karakter individu, interaksi sosial, sosial ekonomi dan kondisi lingkungan. Pola pola perilaku (behavioral patterns) akan selalu berbeda dalam situasi atau lingkungan sosial yang berbeda, dan senantiasa berubah, tidak ada yang menetap (fixed). Gaya hidup merupakan gambaran bagi setiap orang yang mengenakannya dan menggambarkan seberapa besar nilai moral orang tersebut dalam masyarakat disekitarnya. Atau juga, gaya hidup adalah suatu seni yang dibudayakan oleh setiap orang. Gaya hidup juga sangat berkaitan erat dengan perkembangan zaman dan teknologi. Semakin bertambahnya zaman dan semakin canggihnya teknologi, maka semakin berkembang luas pula penerapan gaya hidup oleh manusia dalam kehidupan sehari-hari. Dalam penelitian ini, gaya hidup masyarakat miskin kota dilihat melalui perilaku yang melekat pada pola konsumsi, investasi, pemanfaatan waktu luang, komunikasi dan transportasi, serta keselamatan diri (safety).

\section{METODE PENELITIAN}

\section{Waktu dan Tempat Penelitian}

Penelitian dilaksanakan pada bulan Mei-Juni 2007 dengan lokasi penelitian di Kota Semarang khususnya wilayah yang dikenal sebagai daerah kantong-kantong kemiskinan dan memiliki ciri perkotaan.

\section{Data dan Metode Sampling}

Jenis data yang digunakan dalam penelitian ini adalah data primer, yaitu data yang dikumpulkan dan diolah sendiri oleh sebuah organisasi atau perorangan langsung dari objeknya. Data primer yang dimaksud merupakan data yang didapat/dikumpulkan dan diolah sendiri dari hasil kuesioner yang dilakukan pada beberapa lokasi kemiskinan di Kota Semarang. Teknik pengumpulan data atau alat yang digunakan untuk memperoleh keterangan dari objek dalam penelitian ini yaitu wawancara langsung dan observasi (Pengamatan Langsung).
Populasi dalam penelitian ini adalah masyarakat miskin Kota Semarang. Teknik pengambilan sampel dalam penelitian ini dilakukan dengan metode stratified purposive sampling. Pemilihan sampel dilakukan dengan terlebih dahulu mengklasifikasi suatu populasi kedalam sub-sub populasi berdasarkan karakteristik tertentu dari elemen-elemen populasi. Sampel kemudian dipilih dari setiap sub populasi secara purposif. Penggunaan metode ini lebih menekankan pada heterogenitas karakteristik elemen-elemen pada masingmasing unit sampel, tetapi karakteristik elemenelemen antara kelompok unit sampel satu dengan unit sampel yang lain relatif homogen. Adapun distribusi sampel dalam penelitian ini dapat dilihat gambar 1.

\section{Gambar 2.}

\section{Bagan Teknik Pengambilan Sampel}

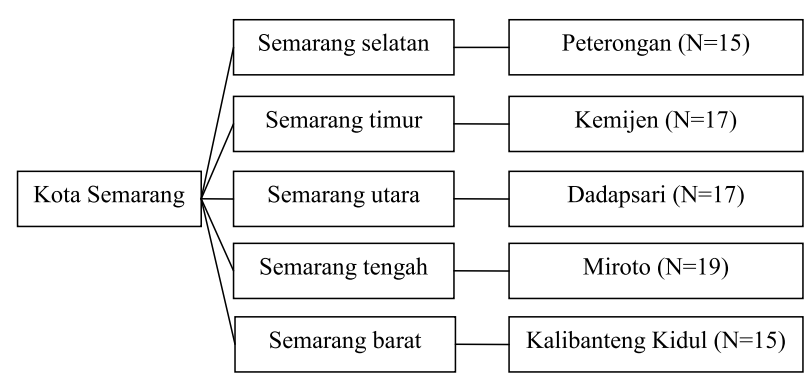

\section{Metode Analisis}

Analisis data pada penelitian ini adalah metode deskriptif statistik. Analisis deskriptif statistik yaitu metode-metode yang digunakan dengan cara mengelompokkan, merangkum dan mempresentasikan data-data dalam suatu cara yang informatif (Mason, 1999). Pada jenis penelitian deskriptif, data yang dikumpulkan berupa kata-kata, gambar, dan bukan angkaangka. Sedangkan menurut Moleong (2005 : 6), penelitian deskriptif nantinya akan berisi kutipan-kutipan data untuk memberi gambaran penyajian laporan tersebut. Data tersebut berasal 
dari naskah wawancara, catatan lapangan, foto, videotape, dokumen pribadi, catatan atau memo, dan dokumen resmi lainnya.

Analisis deskriptif statistik digunakan untuk menganalisa gaya hidup masyarakat miskin kota Semarang. Analisa dilakukan melalui gaya hidup masyarakat miskin yang tercermin dalam perilaku konsumsi, investasi, penggunaan waktu luang (leisure), dan kepedulian responden pada keselamatan jiwa (safety). Data-data yang didapat dari hasil pengumpulan data melalui kuesioner dan wawancara ditabulasi dengan alat analisis SPSS sehingga mudah untuk dipahami dan diinterpretasikan. Tabulasi menyajikan ringkasan, pengaturan atau penyusunan data dalam bentuk tabel numerik. Metode ini digunakan oleh peneliti untuk memberikan informasi mengenai karakteristik variabel penelitian yang digunakan.

\section{HASIL PENELITIAN DAN PEMBAHASAN}

\section{Gambaran Umum Responden}

Sampel yang terkumpul dalam penelitian ini sebanyak 83 responden, yang terdiri dari 49 responden laki-laki dan 34 responden perempuan di mana 4 responden berstatus belum menikah dan 79 responden telah menikah. Sebagian besar responden berada pada usia 60 tahun ke atas yaitu sebanyak 27 responden dan hanya 1 responden yang berusia kurang dari 20 tahun. Untuk usia dari 41 tahun sampai 60 tahun ke atas mayoritas responden mengenyam pendidikan hanya sampai tingkat SD, sedangkan untuk usia 30 tahun ke bawah mayoritas responden berpendidikan sampai SLTA.

Pekerjaan yang paling banyak digeluti oleh responden yaitu wiraswasta dan buruh yaitu masing-maing sebanyak 19 orang, tukang becak 6 orang, pensiunan 4 orang dan 13 orang tidak bekerja. Sisanya terdapat 23 jenis pekerjaan yaitu ibu rumah tangga, karyawan, loper, pelajar, mahasiswa, pelayan, pengasuh anak, penjahit, petani, pocokan, pembantu rumah tangga, satpam, tukang kebun, tukang las, tukang parkir, tukang sapu dan tukang pijat. Mayoritas responden berpenghasilan antara $\mathrm{Rp}$ 200.000,00 sampai kurang dari Rp 200.000,00 yaitu sebanyak 55 responden dan 14 responden tidak berpenghasilan. Untuk responden yang berpenghasilan lebih dari Rp 500.000,00 hanya terdapat 9 orang. Penghasilan yang tergolong rendah ini merupakan dampak dari jenis pekerjaan yang digeluti responden yang sebagian besar adalah jenis pekerjaan dengan pendidikan dan keterampilan yang rendah.

\section{Karakteristik Masyarakat Miskin Kota Sebagai Refleksi Gaya Hidup}

Kebutuhan dasar yang diperlukan oleh masyarakat miskin kota dapat dilihat melalui refleksi gaya hidup responden. Refleksi gaya hidup ini dapat ditinjau dari perilaku konsumsi (sandang, pangan, dan papan), investasi, leisure dan safety. Keempat komponen inilah yang dijadikan rujukan untuk membedah karakteristik masyarakat miskin di Kota Semarang.

\section{Perilaku Konsumsi Masyarakat Miskin Kota}

Perilaku konsumsi masyarakat miskin kota merupakan upaya dari masyarakat miskin kota memenuhi kebutuhan sandang, pangan dan papan. Ketiga kebutuhan tersebut mau tidak mau harus responden penuhi sebagai upaya untuk bertahan hidup. Melalui ketiga kebutuhan ini juga akan dapat diketahui barometer standar kehidupan yang harus dijalani responden. Perilaku konsumsi masyarakat miskin kota yang dilihat melalui sandang, pangan dan papan secara garis besar dapat dilihat pada Tabel 1 . 
Tabel 1.

Karakteristik Masyarakat Miskin Kota dalam Perilaku Konsumsi sebagai Refleksi Gaya Hidup

\begin{tabular}{|c|c|c|c|c|c|}
\hline \multicolumn{6}{|c|}{ Perilaku Konsumsi } \\
\hline \multicolumn{2}{|c|}{ Sandang } & \multirow{2}{*}{$\frac{\text { Pangan }}{\text { Deskripsi }}$} & \multirow[b]{2}{*}{$\%$} & \multicolumn{2}{|l|}{ Papan } \\
\hline Deskripsi & $\%$ & & & Deskripsi & $\%$ \\
\hline $\begin{array}{c}\text { Jumlah } \\
\text { Pakaian yang } \\
\text { Dimiliki }\end{array}$ & & $\begin{array}{c}\text { Intensitas Makan } \\
\text { Keluarga Responden } \\
\text { Dalam Sehari }\end{array}$ & & $\begin{array}{c}\text { Hak Kepemilikan } \\
\text { Rumah }\end{array}$ & \\
\hline 3 & 13,25 & 1 Kali & 1,2 & Milik Sendiri & 74,7 \\
\hline 4 & 15,66 & 2 Kali & 16,47 & Sewa & 15,66 \\
\hline 5 & 21,69 & 3 Kali & 81,13 & Lainnya & 9,64 \\
\hline 6 & 6,02 & 4 Kali & 1,2 & & \\
\hline 7 & 15,66 & & & Kondisi Rumah & \\
\hline 8 & 18,07 & $\begin{array}{c}\text { Menu Makanan } \\
\text { Responden dan } \\
\text { Keluarga } \\
\end{array}$ & & Baik & 14,46 \\
\hline 9 & 2,41 & 2 Sehat & 12,05 & Cukup & 46,99 \\
\hline 10 & 6,02 & 3 Sehat & 66,27 & Kumuh & 3,61 \\
\hline 15 & 1,2 & 4 Sehat & 18,07 & Kurang & 34,94 \\
\hline & & 5 Sehat & 3,1 & & \\
\hline $\begin{array}{c}\text { Anggaran } \\
\text { Pembelian } \\
\text { Baju Selama } \\
\text { Setahun } \\
\end{array}$ & & & & Kondisi Sanitasi & \\
\hline RP 0 & 2,22 & $\begin{array}{l}\text { Banyaknya Kg Beras } \\
\text { untuk Makan Sehari }\end{array}$ & & Baik & 22,89 \\
\hline$\geq \operatorname{Rp} 200.000,00$ & 72,22 & $0,3 \mathrm{Kg}$ & 1,2 & Cukup & 39,76 \\
\hline$\pm \mathrm{Rp} 300.000,00$ & 14,44 & $0,5 \mathrm{Kg}$ & 14,46 & Kurang & 37,35 \\
\hline$\pm \mathrm{Rp} 400.000,00$ & 1,11 & $0,75 \mathrm{Kg}$ & 43,37 & & \\
\hline \pm Rp $500.000,00$ & 1,11 & $1 \mathrm{Kg}$ & 31,33 & Jumlah Kamar & \\
\hline$>$ Rp 500.000,00 & 1,11 & $1,5 \mathrm{Kg}$ & 3,61 & 0 & 4,82 \\
\hline & & $2 \mathrm{Kg}$ & 4,82 & 1 & 25,3 \\
\hline $\begin{array}{c}\text { Intensitas } \\
\text { Pembelian } \\
\text { Baju Selama } \\
\text { Satu Tahun } \\
\end{array}$ & & $3 \mathrm{Kg}$ & 1,2 & 2 & 36,14 \\
\hline 1 Kali & 66,27 & & & 3 & 24,1 \\
\hline 2 Kali & 10,84 & & & 4 & 4,82 \\
\hline 3 Kali & 7,23 & & & 5 & 3,62 \\
\hline Dibelikan & 15,66 & & & 7 & 1,2 \\
\hline $\begin{array}{c}\text { Waktu } \\
\text { Pembelian }\end{array}$ & & & & $\begin{array}{c}\begin{array}{c}\text { Peralatan } \\
\text { Rumah Tangga }\end{array} \\
\end{array}$ & \\
\hline Ketika ada uang & 13,25 & & & Lengkap & 7,23 \\
\hline Hari Raya & 68,67 & & & Tidak Lengkap & 92,77 \\
\hline Lainnya & 18,07 & & & & \\
\hline
\end{tabular}

Sumber: data primer yang diolah, 2007

Karakteristik responden melalui variabel sandang dapat diketahui melalui indikator jumlah pakaian yang dimiliki, anggaran yang disediakan untuk membeli pakaian dalam setahun, waktu yang sering digunakan untuk membeli pakaian dan intensitas membeli pakaian dalam setahun. Secara umum kondisi responden dalam memenuhi kebutuhan sandang responden tergolong masih sangat kurang. Hal ini dapat dilihat dari jumlah pakaian yang dimiliki oleh responden paling banyak adalah sebesar 5 pasang dengan persentase sebesar $21,69 \%$ dan anggaran untuk membeli pakaian yang kurang dari $\mathrm{Rp}$ 200.000,00 untuk pembelian baju selama satu tahun. Anggaran yang sekecil itu dikarenakan mayoritas responden membeli baju selama satu tahun satu kali dan biasanya menjelang hari raya. Itupun kebanyakan diperuntukkan hanya untuk anak-anak responden. Bahkan, sebagian responden ada yang tidak mengeluarkan biaya sama sekali untuk mendapatkan pakaian $(2,22$ $\%$ ), hal ini disebabkan karena responden tersebut biasanya mendapatkan pakaian secara cumacuma dari kerabat, tetangga dan orang lain yang merasa prihatin melihat nasib responden tersebut.

Selain sandang, pemenuhan kebutuhan yang sangat primer lainnya yaitu pangan. Dalam penelitian ini, karakteristik responden melalui aspek pangan dapat dilihat dengan indikator intensitas makan keluarga responden dalam sehari, frekuensi makan responden dalam sehari, menu makanan responden dan banyaknya konsumsi beras dalam satu hari.

Kondisi yang sama juga terjadi dalam perilaku konsumsi responden untuk memenuhi kebutuhan pangan. Walaupun sebagian besar responden dan keluarga responden dalam satu hari makan sebanyak tiga kali, bukan berarti kebutuhan gizi responden telah tercukupi. Ini terlihat dari menu makanan yang dikonsumsi sebagian besar responden hanya memenuhi 3 sehat saja dan banyaknya beras yang dikonsumsi sebagian besar responden kurang dari $1 \mathrm{Kg}$ untuk setiap harinya.

Ketidaklayakan pemenuhan kebutuhan hidup responden pun terlihat pada tempat tinggal responden, lingkungan yang kumuh dan sanitasi yang kurang baik, harus dirasakan oleh beberapa responden walaupun sebagian responden sudah ada yang tinggal di lingkungan yang baik. Namun dalam hal kepemilikan rumah, sebagian besar responden sudah memiliki rumah sendiri dan 
paling banyak dalam satu rumah hanya terdapat 2 kamar. dari 83 responden yang ada, 74,7\% hak kepemilikan rumahnya adalah milik sendiri dan $15,66 \%$ dari responden menyatakan bahwa responden menyewa. Sebagian besar responden $(46,99 \%)$ dari 83 responden mempunyai rumah dengan kondisi yang cukup baik, 39,94\% kurang baik dan kumuh sebesar 14,46\%. Adapun kondisi sanitasi rumah dapat disimpulkan bahwa 39,76 $\%$ rumah responden cukup baik sedangkan 37,35 $\%$ adalah kurang baik. Kondisi tempat tinggal ini akan sangat berdampak terhadap sang penghuni, baik terhadap masalah kesehatan maupun kenyamanan.

\section{Perilaku Investasi Masyarakat Miskin Kota}

Dalam upaya meningkatkan taraf hidupnya, masyarakat miskin kota seharusnya tidak mengkesampingkan investasi. Terutama investasi yang berupa Human Invesment. Investasi ini tidak lain berfungsi dalam upaya untuk mendorong perkembangan aset dan jaminan masa depan. Untuk melihat perilaku investasi, secara sederhana dapat ditinjau dari kepemilikan tabungan, pendidikan tertinggi yang sedang atau telah dijalani anak responden dan kesehatan. Tabungan merupakan bentuk kesiapan responden dalam menghadapi keperluan masa depan, pendidikan tertinggi anak secara tidak langsung merupakan jaminan bagi responden dalam menghadapi hari tua dan kesehatan akan mendukung produktivitas responden dan keluarga. Karakteristik masyarakat miskin Kota Semarang dalam perilaku investasi dapat dilihat pada Tabel 2.

Pendapatan yang rendah menyebabkan $73,49 \%$ dari 83 respoden tidak mempunyai tabungan dan hanya $26,51 \%$ saja yang menabung. Jerat kemiskinan melalui jalur pendidikan pun terjadi dalam penelitian ini. Pendidikan orang tua yang rendah ternyata juga diikuti oleh pendidikan anak yang rendah pula, di mana mayoritas pendidikan responden dan anaknya hanya sebatas sekolah dasar. Untuk masalah kesehatan, sebagian besar responden $(46,99 \%)$ tidak mengeluarkan anggaran untuk berobat dikarenakan memiliki kartu Askin yang dapat digunakan untuk berobat secara gratis di puskesmas atau rumah sakit sesuai dengan ketentuan. Selain itu, responden juga masih memiliki kepedulian terhadap kesehatan badan dengan baik. Setidaknya responden masih mau berobat untuk mengobati penyakit yang sedang responden derita.

\section{Tabel 2.}

\section{Karakteristik Masyarakat Miskin Kota} dalam Perilaku Investasi sebagai Refleksi Gaya Hidup

\begin{tabular}{|c|c|c|c|c|c|}
\hline \multicolumn{6}{|c|}{ Perilaku Investasi } \\
\hline Deskripsi & $\%$ & Deskripsi & $\%$ & Deskripsi & $\%$ \\
\hline $\begin{array}{c}\text { Kepemilikan } \\
\text { Tabungan oleh } \\
\text { Responden }\end{array}$ & & $\begin{array}{c}\text { Tingkat } \\
\text { Pendidikan } \\
\text { Anak }\end{array}$ & & $\begin{array}{c}\text { Jenis Penyakit } \\
\text { yang Sering } \\
\text { Diderita } \\
\text { Responden }\end{array}$ & \\
\hline $\mathrm{Ya}$ & 26,51 & Tidak Sekolah & 10,84 & Asam Urat & 3,61 \\
\hline \multirow[t]{2}{*}{ Tidak } & 73,49 & SD & 13,25 & Darah Tinggi & 1,2 \\
\hline & & SMP & 37,35 & Diare & 2,41 \\
\hline $\begin{array}{l}\text { Tingkat } \\
\text { Pendidikan } \\
\text { Responden }\end{array}$ & & SMA & 31,33 & Flu & 31,33 \\
\hline Tidak Sekolah & 7,23 & S1 & 7,23 & Masuk Angin & 43,37 \\
\hline SD & 44,58 & & & Sakit Kepala & 14,46 \\
\hline SMP & 20,48 & $\begin{array}{l}\text { Anggaran } \\
\text { Kesehatan }\end{array}$ & & Rematik & 2,41 \\
\hline \multirow[t]{5}{*}{ SMA } & 27,71 & Rp0 & 66,27 & Stroke & 1,2 \\
\hline & & $\begin{array}{l}\text { Rp 1.000,00 - } \\
\operatorname{Rp} 5.000,00\end{array}$ & 14,47 & & \\
\hline & & $\begin{array}{l}\text { Rp 7.000,00- } \\
\operatorname{Rp} 14.000,00\end{array}$ & 4,81 & & \\
\hline & & $\begin{array}{l}\text { Rp 20.000,00- } \\
\operatorname{Rp} 25.000,00\end{array}$ & 8,43 & & \\
\hline & & $\begin{array}{l}\text { Rp } 30.000,00- \\
\text { Rp } 50.000,00\end{array}$ & 6,02 & & \\
\hline
\end{tabular}

Sumber: data primer yang diolah, 2007

\section{Pemanfaatan Waktu Luang (Leisure) dari Masyarakat Miskin Kota}

Untuk mengisi waktu luang, kegiatan rekreasi merupakan bentuk gaya hidup bagi siapapun juga termasuk masyarakat miskin. Setidaknya dalam kehidupan responden, responden pernah melakukan rekreasi atau mungkin sekedar jalan-jalan biasa walaupun ada yang tergolong jarang. Tetapi karena keterbatasan penghasilan, tempat rekreasi yang sering dikunjungi responden pun tergolong masih sekitar Kota Semarang. 
Tabel 3.

Karakteristik Masyarakat Miskin Kota dalam Pemanfaatan Waktu Luang (Leisure) sebagai Refleksi Gaya Hidup

\begin{tabular}{|c|c|c|c|c|c|}
\hline \multicolumn{6}{|c|}{ Pemanfaatan Waktu Luang (Leisure) } \\
\hline \multicolumn{2}{|c|}{ Rekreasi } & \multicolumn{2}{|c|}{$\begin{array}{c}\text { Komunikasi dan } \\
\text { Informasi }\end{array}$} & \multicolumn{2}{|c|}{ Transportasi } \\
\hline Deskripsi & $\%$ & Deskripsi & $\%$ & Deskripsi & $\%$ \\
\hline $\begin{array}{l}\text { Intensitas } \\
\text { Berekreasi }\end{array}$ & 38,55 & $\begin{array}{c}\text { Jenis Alat } \\
\text { Komunikasi }\end{array}$ & & $\begin{array}{c}\text { Jenis Alat } \\
\text { Transportasi } \\
\text { Untuk bekerja }\end{array}$ & \\
\hline Jarang & 53,01 & HP & 28,92 & Angkutan Umum & 48,19 \\
\hline Pernah & 8,43 & Surat & 4,82 & Becak & 4,82 \\
\hline \multirow[t]{2}{*}{ Sering } & & Wartel & 57,83 & Jalan Kaki & 14,46 \\
\hline & & Wartel/HP & 1,2 & Sepeda & 14,46 \\
\hline $\begin{array}{l}\text { Tempat } \\
\text { Tujuan } \\
\text { Rekreasi }\end{array}$ & 1,2 & Lainnya & 7,23 & Sepeda Motor & 14,46 \\
\hline Bandungan & 1,2 & & & Lainnya & 3,61 \\
\hline Goa Jatijajar & 1,2 & Media & & & \\
\hline Kaligawe & 1,2 & Koran & 1,2 & $\begin{array}{l}\text { Jenis Alat } \\
\text { Transportasi } \\
\text { untuk Sekolah } \\
\text { anak }\end{array}$ & \\
\hline Kendal & 1,2 & Radio & 2,41 & Angkutan Umum & 26,51 \\
\hline Kudus & 1,2 & Televisi & 55,42 & Jalan Kaki & 12,05 \\
\hline Tawangmangu & 1,2 & $\begin{array}{l}\text { Televisi/ } \\
\text { Koran }\end{array}$ & 4,82 & Sepeda & 18,07 \\
\hline Mall & 19,28 & Televisi/Radio & 24,1 & Sepeda Motor & 2,41 \\
\hline Simpang Lima & 15,66 & $\begin{array}{l}\text { Televisi/ } \\
\text { Radio/Koran }\end{array}$ & 2,41 & Lainnya & 40,96 \\
\hline Marina & 2,41 & Lainnya & 9,64 & & \\
\hline Wonderia & 20,48 & & & $\begin{array}{l}\text { Kepemilikan } \\
\text { Kendaraan } \\
\text { Pribadi }\end{array}$ & \\
\hline Tidak Tentu & 15,66 & $\begin{array}{c}\text { Biaya } \\
\text { Komunikasi } \\
\text { dan } \\
\text { Informasi } \\
\text { Sebulan }\end{array}$ & & Sepeda & 25,3 \\
\hline Tidak Pernah & 12,05 & $\begin{array}{l}\text { Rp 2.500,00 - } \\
\operatorname{Rp} 5.000,00\end{array}$ & 26,91 & Sepeda Motor & 15,66 \\
\hline \multirow[t]{2}{*}{$\begin{array}{l}\text { Kawasan } \\
\text { Semarang } \\
\text { Lainnya }\end{array}$} & & $\begin{array}{l}\text { Rp } 10.000,00 \\
-\operatorname{Rp} \\
20.000,00\end{array}$ & 15,66 & $\begin{array}{l}\text { Sepeda dan Sepeda } \\
\text { Motor }\end{array}$ & 3,61 \\
\hline & & $\begin{array}{l}\text { Rp } 30.000,00 \\
-R p \\
40.000,00\end{array}$ & 10,84 & Tidak Punya & 55,41 \\
\hline $\begin{array}{l}\text { Biaya } \\
\text { Rekreasi }\end{array}$ & 30,12 & $\begin{array}{l}\text { Rp 50.000,00 } \\
- \text { Rp } \\
60.000,00\end{array}$ & 9,63 & & \\
\hline $\mathrm{Rp} 0$ & 8,43 & $\begin{array}{l}\text { Rp } 100.000,00 \\
-\operatorname{Rp} \\
170.000,00\end{array}$ & 2,4 & & \\
\hline $\begin{array}{l}\mathrm{Rp} 5.000,00- \\
\mathrm{Rp} 15.000,00\end{array}$ & 10,84 & Rp 200.000,00 & 1,2 & & \\
\hline $\begin{array}{l}\text { Rp } 20.000,00- \\
\text { Rp } 40.000,00\end{array}$ & 15,66 & Tidak Tahu & 28,92 & & \\
\hline Rp $50.000,00$ & 3,61 & & & & \\
\hline Rp $100.000,00$ & 31,33 & & & & \\
\hline Tidak tentu & & & & & \\
\hline
\end{tabular}

Sumber: data primer yang diolah, 2007
Dengan intensitas sering, tempat yang sering dikunjungi oleh responden antara lain Bandungan, Goa Jatijajar, Kaligawe, Kendal, Kudus, Tawangmangu, dan kawasan sekitar Semarang seperti Simpang Lima, Pantai Marina, Wonderia, Mall, Klenteng Sam Poo Kong dan Lawang Sewu. Dengan mayoritas responden yang hanya berekreasi di sekitar Semarang menyebabkan anggaran untuk berekreasi tergolong rendah, kurang dari Rp 50.000,00, bahkan ada yang tidak mengeluarkan biaya dan tidak memiliki anggaran tertentu (Tabel 3).

\section{Komunikasi dan Transportasi Masyarakat Miskin Kota}

Sesuai dengan kodrat manusia yang pastinya membutuhkan orang lain (makhluk sosial) dan harus berhubungan dengan orang lain, terlebih lagi jika dipisahkan oleh jarak yang jauh maka diperlukan sarana komunikasi dan transportasi. Selain hanphone dan surat, wartel merupakan alat komunikasi yang banyak dipakai oleh mayoritas responden. Televisi juga merupakan media informasi yang paling banyak dipakai oleh responden. Adapun anggaran untuk komunikasi dan informasi tergolong variatif.

Sarana transportasi diperlukan guna mendukung kegiatan sehari-hari baik untuk sarana bekerja maupun sarana untuk anak bersekolah. Angkutan umum adalah sarana transportasi yang banyak dipakai baik oleh responden sendiri maupun oleh anak responden untuk bersekolah. $\mathrm{Hal}$ ini terkait dengan sebagian besar responden $(53,01 \%)$ yang tidak memiliki kendaraan pribadi. Kendaraan pribadi seperti sepeda, sepeda motor merupakan barang yang sulit dibeli oleh responden terkait dengan keterbatasan ekonomi yang responden alami (Tabel 3). 
Tabel 4.

Karakteristik Masyarakat Miskin Kota dalam Perilaku Kepedulian Terhadap Keselamatan Diri (Safety) sebagai Refleksi Gaya Hidup

\begin{tabular}{|c|c|l|c|c|c|}
\hline \multicolumn{7}{|c|}{ Perilaku Kepedulian terhadap Keselamatan Diri (Safety) } \\
\hline Deskripsi & $\%$ & \multicolumn{1}{|c|}{ Deskripsi } & $\%$ & \multicolumn{1}{|c|}{ Deskripsi } & $\%$ \\
\hline $\begin{array}{c}\text { Kepedulian } \\
\text { Terhadap } \\
\text { Keselamatan } \\
\text { Diri }\end{array}$ & $\begin{array}{c}\text { Penggunaan Alat } \\
\text { Pengaman }\end{array}$ & $\begin{array}{c}\text { Kepedulian } \\
\text { Terhadap } \\
\text { Kebersihan }\end{array}$ & \\
\hline Peduli & 98,8 & Menggunakan & 9,64 & Ya & 83,13 \\
\hline Tidak & 1,2 & $\begin{array}{l}\text { Tidak } \\
\text { Menggunakan }\end{array}$ & 90,36 & Tidak & 16,87 \\
\hline
\end{tabular}

Sumber: data primer yang diolah, 2007

\section{Perilaku kepedulian Terhadap Keselamatan Diri (Safety)}

Dengan pertanyaan yang berkaitan dengan soul value yang diajukan, jawaban yang mutlak dari responden tentang kepedulian responden terhadap keselamatan diri tidak tercermin pada penggunaan alat pengaman. Walaupun responden sebagian besar menyadari arti penting kesehatan dan keselamatan yaitu hampir seratus persen responden mengaku peduli terhadap keselamatan jiwa responden, tetapi kurang lebih hanya sepuluh persen saja yang menggunakan alat pengaman dalam bekerja. Bahkan melalui pertanyaan yang berkaitan dengan kebersihan, masih ada sekitar $15 \%$ responden yang merasa tidak peduli dengan kebersihan (Tabel 4).

\section{KESIMPULAN DAN SARAN}

\section{KESIMPULAN}

1. Sebagian besar responden berusia lebih dari 51 tahun dan mengenyam pendidikan sampai SD dan bahkan ada yang tidak sekolah. Hal ini disebabkan karena adanya keterbatasan ekonomi sehingga para responden tidak bisa mengenyam pendidikan yang lebih baik.

2. Sebagian besar responden memiliki pakaian lebih dari 4 pasang dan hanya memiliki anggaran kurang dari Rp 200.000,00. Hal itu dikarenakan sebagian responden membeli baju selama satu tahun satu kali yang biasanya dibeli menjelang hari raya.
3. Belum tercukupinya kebutuhan gizi masih terlihat pada pola makan sebagian besar responden dan keluarga responden dalam satu hari makan sebanyak tiga kali. Walaupun ada responden yang makan 4 kali dalam sehari namun hanya sebesar $1,2 \%$, jumlah ini sama dengan responden yang makan 1 kali sehari.

4. Kondisi yang tidak layak dalam pemenuhan kebutuhan hidup responden pun terlihat pada kondisi tempat tinggal, lingkungan yang kumuh dan sanitasi yang kurang baik harus dirasakan oleh beberapa responden walaupun sebagian responden sudah ada yang tinggal di lingkungan yang baik.

5. Kepedulian terhadap keselamatan jiwa masih besar pada diri responden. Ditunjukkan oleh jawaban yang mutlak dari responden tentang kepedulian responden terhadap keselamatan diri, tetapi tidak tercermin pada penggunaan alat pengaman. Walaupun responden sebagian besar menyadari arti penting kesehatan dan keselamatan

6. Untuk mengisi waktu luang responden lebih memilih rekreasi atau jalan-jalan sekitar Kota Semarang saja. Hal itu didasari oleh besarkecilnya anggaran yang dimiliki responden dan aksesnya yang mudah.

\section{SARAN}

Berdasarkan uraian dan temuan-temuan yang telah dikemukakan di atas, dapat ditarik beberapa saran sebagai berikut:

1. Revitalisasi kelembagaan yang ada terkait dengan pengentasan kemiskinan di Kota Semarang melalui program-program yang sesuai dengan karakteritik gaya hidup yang dimiliki oleh masyarakat miskin. Harapannya adalah program yang tercipta mampu menyentuh masyarakat miskin secara utuh.

2. Masyarakat disarankan dapat mendukung dan berpartisipasi aktif dalam program pemberdayaan masyarakat miskin disekitar lingkungannya. Hal ini dapat dilakukan 
melalui aktif langsung dalam pemberdayaan menurut perannya masing-masing.

3. Pendekatan kelembagaan antara masyarakat, lembaga swadaya masyarakat, dan pemerintah perlu ditingkatkan terutama dalam mensinergikan segala program pengentasan kemiskinan yang ada terutama dalam pemenuhan kebutuhan dasar masyarakat miskin dan mendorong perilaku investasinya.

4. Akademisi disarankan dapat mengkaji dan meneliti lebih komprehensif mengenai masyarakat miskin kota, terutama untuk memutus lingkaran kemiskinan yang ada.

\section{DAFTAR PUSTAKA}

Alam, Veronika Shinta Prima. 2006. Hubungan antara Gaya Hidup Achievers dengan Minat Menggunakan Kartu Kredit Pada Pegawai Wanita Sekretariat Daerah Propinsi Jawa Tengah. Skripsi: Program Studi Psikologi Fakultas Kedokteran Universitas Diponegoro, Semarang.

Bambang, dkk. (2006). Evaluasi dari Aplikasi Pendidikan Lingkungan Dalam Proses Pembelajaran di Kota Semarang. FE Undip

Badan Pusat Statistik. (2006). Penduduk Muskin (PoorPopulation). Berita Resmi Statistik Penduduk Miskin. Propinsi Jawa Tengah

Badan Pusat Statistik. (2006). Daftar Masyarakat Penerima BLT . BPS Kota Semarang.

Baharoglu, Deniz and Christine Kessides. 2001. Urban Poverty in World Bank, PRSP Sourcebook, World Bank, Washington DC.

Bappenas. 2004. Strategi Nasional Penanggulangan Kemiskinan Bab II diakses melalui http://www.bappenas.go.id/index. php pada tanggal 9 April 2007.
Brockerhorff, M dan Brennan. 1998. "The Poverty of Cities in Developing Regions". Population and Development Review 24, no. 1.

Cahyat, Ade. 2004. Bagaimana Kemiskinan Diukur? Beberapa Model Penghitungan Kemiskinan di Indonesia. Center for International Forestry Research: Governance Brief, No. 2, November.

Chambers, Robert. 2006. "Poverty Unperceived: Traps, Biases and Agenda". Institute of Development Studies at the University of Sussex Brighton BN1 9RE, UK.

Gunawan dan Sugiyanto. (2005). Kondisi Keluarga Fakir Miskin. http://www. depsos.go.id/Balatbang/Puslitbang\%20 UKS/2005/gunawan.htm

Dowling, Malcolm dan Ma Rebecca Valenzuela. (2004). Economic Development In Asia. Singapura: Thomson Asia Pte Ltd

Mason, Robert D. Douglas A. Lind and William G. Marchal. (1999). Statistical Techniques in Business and Economics. Tenth Edition. McGraw Hill. International Edition.

McKay, Andrew dan Abbi M.Kedir. 2005. Chronic Poverty in Urban Ethiopia : Panel Data Evidence dalam Jurnal Internasional Planning Studies Vol.10, No.1, 49-67.

Meier, Gerald M dan Joseph E. Stiglitz. 2000. Frontiers of Development Economics, The Future in Perspective. Worl Bank and Oxford University Press.

Moleong, Lexy J. (2005). Metodologi Penelitian Kualitatif. Bandung : PT. Remaja Rosdakarya.

Rima, dkk. (2006). Analisis Perbedaan Pola Hidup Dan Konsumsi Mahasiswa Kost Fakultas Ilmu Sosial Dengan Fakultas Ilmu Eksakta Di Universitas Diponegoro Semarang. FE Undip 
Shalimow. 2004. Pemberdayaan Sektor Informal Masyarakat Melalui P2KP diakses melalui http://shalimow.com/ pemberdayaan/pemberdayaan-sektorinformal-masyarakat-melalui-p2kpsekedar-abstraksi.html pada tanggal 14 April 2008.

Sumodiningrat, Gunawan. 1998. Membangun Perekonomian Rakyat. Yogyakarta : Pustaka Pelajar.

Suryawati, Criswardani. 2005. Memahami Kemiskinan Secara Multidimensional. http://www.jmpk-online.net/Volume 8/Vol_08_No_03_2005.pdf. Diakses tanggal 11 November 2009.
Susilowati, Indah. (2003). Studi Penghayatan Cinta Lingkungan Siswa dan Mahasiswa di Perkotaan (studi kasus di beberapa sekolah menengah atas dan universitas di kota Semarang). Dinamika Pembangunan, Vol. 4, No.2, Desember 2003, 124-133

Todaro, Michael P dan Stephen C Smith. (2003). Pembangunan Ekonomi di Dunia Ketiga. Jakarta : PT Erlangga.

World Health Organization .1998. Life in The 21st Century A Vision for All. Geneva: WHO Library Cataloguing in Publication Data. 